\title{
Humor-the Reform and Innovation of Teaching Language in Teaching
}

\author{
Yu-ling $\mathrm{ZHAO}^{1}$ \\ ${ }^{1}$ Northeast Dianli University, Jilin 132012, \\ Jilin, China \\ Zhuo ZHANG* 2 \\ ${ }^{2}$ China-Japan Union Hospital, Jilin University, \\ Changchun 130033, Jilin, China \\ ${ }^{*}$ Corresponding author \\ Hai-yan ZHANG ${ }^{2}$ \\ ${ }^{2}$ China-Japan Union Hospital, Jilin University, \\ Changchun 130033, Jilin, China
}

\begin{abstract}
The teaching, not to try to arouse the desire of students for seeking knowledge, is just like a piece of cold iron being hammered, said American educator Mann. With humor in teaching, the desire of students for knowledge can be effectively stimulated, and also students are helped to understand and grasp what they learn.
\end{abstract}

Keywords: Teaching; Humor; Reform

\section{INTRODUCTION}

Humor is a kind of wisdom, art, life skills, and attitude towards life. People's thinking and imagination can be enriched by it. If humor is used by teachers in colleges and universities, the distance between teachers and students can be reduced, and activating classroom atmosphere, sending out sparks wisdom, and improving the classroom efficiency can be achieved. Humor is a language with ideological and artistic elements. Humor languages are not honest words, in which wisdom, cleverness, and all sorts of funny skills are used for promoting people to laugh and feel amazed in reading, not to know whether to laugh or cry, or to be educated. This truth can be understood after the works of Dickens, Mark Twain, and Gogol is read.

\section{The distinctive feature of humor-laughing}

A distinctive feature of humor lies in laughing. Laughing is the most important feature of humor.
As an art of laughing, humor give a person a kind of kind smile containing philosophical and well-meaning - a few words often become rich in wisecracks and contain a deep meaning, so that people feel amazing and cannot help laughing. When smile ends, the contained wisdom and philosophy can be understood. However, humor, different from the unctuous, deliberately mystified words, must be funny but also rigorous, and charming but also free from vulgarity, and this is because too much guile and cunning will be disdained by students and ultimately an opposite effect emerges. This point needs to be controlled especially well in the use of humor. In general, implying sobriety in humor and sticking to the bark must be simultaneously taken into consideration in the creation and use of humor. In this way, a proper and best teaching effect can be played.

\section{Necessary qualities of humorous teachers}

Humor is an important part of language art and the proper use of it will greatly enhance the appeal of language. Humor language in teaching refers to the implicit but refined, witty but interesting, meaningful, and philosophical language used teachers on the basis of the actual teaching conditions and contents, which gives people enlightenment and also is a crystallization of the wisdom of teachers. An unexpected effect will be received if it humor language is properly used in classroom teaching.

Humor, as a type of teaching art, does not happen randomly. Several qualities as follows are 
necessarily available in a teacher with a sense of humor. First, keen powers of observation are possessed by a humorous teacher to let the joyful, surprised, doubtful, and embarrassed inner activities of students not to escape from his or her eyes. Second, quick thinking ability exists in a humorous teacher to promote him or her to rapidly analyzed decisions and seek the best solutions after accessing to information through observations. Third, good emotional self-control is necessary, so that the teacher can calmly cope with problems, make advance preparation, and easily solve any questions. Fourth, a humorous attitude is important to keep a happy, fresh, and optimistic state of mind, aiming to activate teaching thinking. Fifth, certain humor skills and great learnings are needed, so as to extemporaneously play under uncertain occasions. In addition, good teaching skills are necessary for a humorous teacher, and otherwise he or she is not humorous if the classroom is not in control.

\section{The important role of humor}

Humor has an important role in teaching: students' interest in learning is stimulated by it and then what students have learned can be better understood and consolidated; classroom atmosphere becomes active and then students' physical and mental fatigue is eliminated, promoting students to form good personality traits. Therefore, the humorous factors must be explored by teachers from teaching materials using great efforts, and teaching methods full of humors can be designed for letting students to acquire knowledge and develop ability in a pleasant atmosphere. Humor is an important symbol of a teacher's charm, vitality, and ability, a concentrative reflection to a teacher's knowledge, wisdom, inspiration, and self-cultivation in the teaching, a different way of improving a teacher's self-influence and creativity, and an important method of improving the teaching effect. Humor helps to create good classroom atmosphere. In humors, there are funniness, wisdom, and highlighted personal characteristics. Good thinking and deep ability in inspiration outbreak can be produced only if instinctual humorous, witty personality is in collision with a variety of mental factors. Teaching humor needs healthy personality and psychological factors as supports, in order to cultivate a sound personality and psychological quality. However, teaching humor and wittiness must be played in a proper scope, and the personalized teaching can be naturally and unrestrictedly deduced if a teaching space can be smoothly expanded, to achieve a humorous effect making students inspired in happiness but not deviating from its original purpose. Eventually, the enthusiasm of teachers and students for classroom teaching and learning is aroused.

\subsection{Activating classroom atmosphere}

Classroom atmosphere is an irrational factor to influence and enhance the teaching art effect, but also an important part of classroom teaching art situation. Classroom atmosphere can become effectively active along with the rapid influence and emotional appeal of good teaching humor art. Teaching practice tells people that a positive atmosphere can be created with laughter in class to promote "teaching" and "learning" to become easy and effective. With the use of teaching humor, students can actively participate in the creative thinking activities in the active classroom teaching atmosphere and can promote the classroom teaching to become vivid and dramatic with teachers. Thus, a good teaching art atmosphere is jointly created.

\subsection{A harmonious relationship between teachers and students}

The studies of anthropologists indicate that humor in human society can play a role like relief valve in alleviating the interpersonal tensions, and it can remedy misunderstandings, explain blames, ease intensions, weaken contradictions, and relieve anxiety. Education practice shows that all requests from educators are rejected by students if teachers and students are in opposite emotion, thus hindering students to get a real 
understanding of correct cognitions. This is the so-called "meaning obstacle". Teaching humor is a good remedy for harmonizing the relationship between teachers and students and eliminating the meaning obstacles. In addition, teachers can calmly avoid an awkward or uncomfortable situation sometimes if they can tactfully and easily become humorous, and thus the teaching environment changes.

\subsection{Stimulating students' desire for seeking knowledge}

Some foreign studies found that students will pay more attention to the teaching and have better learning results, if an example of humor is provided immediately after a concept is introduced and then a detailed explanation is made.

\section{Necessary for teachers to correctly use humor language}

The greatest charm of humor language can be played if it is properly used. First, the artistic style of humor must be elegant to suit both refined and popular tastes, but not random, inferior and vulgar. Second, humor is used by closely combining with classroom teaching, but it can be only used as an aided tool, but not the major teaching method. It is noticeable that humor should be controlled well in use, but not be excessive. A teacher must be a person with humorous quality to make use of humor language well. Humor is a kind of beautiful, healthy quality, said Lenin. The water is unable to carry a ship if it is not deep enough, said Zhuangzi. Precise, appropriate and humorous language is an external embodiment to the inspiration of a teacher, but also a result of the accumulation of profound learning. Therefore, the cultivation of ideology and culture and the enrichment of self-language must be strengthened by teachers. Only in this way, students can be placed by teachers in a beautiful cultural atmosphere and profound language environment, to be educated and influenced.

\section{Conclusion}

The first and foremost assistant of an educationist is humor, said educator Svetlov. The true state of life lies in the exchange between relaxation and tension, and there is no exception to a teaching method, but the best way of creating a relaxed teaching atmosphere is nothing but humor. In teaching, lullabies seem to be sung to students if teaching contents and language are mechanical and tasteless, and thus, students will feel sleepy; teaching objectives can be achieved in a jovial mood if humor language is used well by teachers to promote students to easily and happily learn the intension of knowledge. In the modern teaching, students are required to learn how to learn and also keep happy in learning. To achieve such a goal, there are many methods, of which humor is important. Thus, it is necessary for teachers to improve the literacy of teaching humor art and master the related essential skills.

\section{References}

[1] Yongmei HU. Education Statistics and SPSS Software Application [M]. Beijing: Beijing Normal University Press, 2002.

[2] Ding-ren LI, Ji-cun XU. Twenty Years of Teaching and Learning Theory M]. Beijing: People's Education Press, 2001.

[3] Boyi QIAN. University Teaching Theory [M]. Hefei: China University of Science and Technology Publishing House, 1991.

[4] An-bang XIE. A Comparison of Higher Education [M]. Guilin: Guangxi University Press, 2002 